\title{
Adsorption of Copper from an Ammonia-Thiosulfate Media Using DOWEX 550A Ion Exchange Resin
}

\author{
Cristian Vargas*, Patricio Navarro \\ Departamento de Ingeniería Metalúrgica, Universidad de Santiago de Chile, Santiago, Chile \\ Email: *cristian.vargas@usach.cl
}

How to cite this paper: Vargas, C. and Navarro, P. (2016) Adsorption of Copper from an Ammonia-Thiosulfate Media Using DOWEX 550A Ion Exchange Resin. International Journal of Nonferrous Metallurgy, 5, 33-44.

http://dx.doi.org/10.4236/ijnm.2016.54005

Received: March 25, 2016

Accepted: October 8, 2016

Published: October 11, 2016

Copyright $\odot 2016$ by authors and Scientific Research Publishing Inc. This work is licensed under the Creative Commons Attribution International License (CC BY 4.0).

http://creativecommons.org/licenses/by/4.0/

\begin{abstract}
The study of copper adsorption onto ion exchange resins of anionic type is part of the gold recovery from ammonia-thiosulfate solutions, where copper is the main impurity of the system because it acts as a catalyst of gold dissolution reaction. A study is made of the adsorption and desorption of copper in the form of the $\mathrm{Cu}\left(\mathrm{S}_{2} \mathrm{O}_{3}\right)_{2}^{3-}$ complex in an ammonia-thiosulfate media on an ion exchange resin, DOWEX 550A, classified as a strong base, which in its inner structure has a quaternary amine functional group. In the studied $\mathrm{pH}$ range copper adsorption increased with increasing $\mathrm{pH}$, while the presence of thiosulfate decreased it, the same as the ammonia content, due to the greater presence of cuprotetramine, $\mathrm{Cu}\left(\mathrm{NH}_{3}\right)_{4}^{2+}$. Elution of the copper complexes from the resin was more efficient with sulfite than with perchlorate.
\end{abstract}

\section{Keywords}

Adsorption, Desorption, Copper, Ion Exchange Resin, Ammonia-Thiosulfate

\section{Introduction}

The study of copper adsorption on anion exchange resins has to do with the recovery of gold as $\mathrm{Au}\left(\mathrm{S}_{2} \mathrm{O}_{3}\right)_{2}^{3-}$ present in the solutions produced by leaching gold ores in an ammonia-thiosulfate media, where copper is the main impurity in the system. The ammonia-thiosulfate system with copper offers high gold leaching rates compared to the cyanide system, because the reaction is catalyzed by cupric ions [1]-[23]. The main reaction in the gold leaching in a thiosulfate-ammonia media is the following:

$$
\mathrm{Au}^{0}+\mathrm{Cu}\left(\mathrm{NH}_{3}\right)_{4}^{2+}+5 \mathrm{~S}_{2} \mathrm{O}_{3}^{2-} \rightarrow \mathrm{Au}\left(\mathrm{S}_{2} \mathrm{O}_{3}\right)_{2}^{3-}+\mathrm{Cu}\left(\mathrm{S}_{2} \mathrm{O}_{3}\right)_{3}^{5-}+4 \mathrm{NH}_{3}
$$


With the oxidation reactions of $\mathrm{Cu}^{+}$to $\mathrm{Cu}^{2+}$ through the following equilibrium:

$$
4 \mathrm{Cu}\left(\mathrm{S}_{2} \mathrm{O}_{3}\right)_{3}^{5-}+\mathrm{O}_{2}+2 \mathrm{H}_{2} \mathrm{O}+16 \mathrm{NH}_{3} \rightarrow 4 \mathrm{Cu}\left(\mathrm{NH}_{3}\right)_{4}^{2+}+12 \mathrm{~S}_{2} \mathrm{O}_{3}^{2-}+4 \mathrm{OH}^{-}
$$

The solutions resulting from gold leaching contain gold-thiosulfate, copper-ammonia and copper-thiosulfate complexes, plus tetrathionate in different proportions as a function of the concentrations of copper, ammonia, thiosulfate, and $\mathrm{pH}$.

Recovery of the gold dissolved in the rich leaching solution can take place by activated carbon, solvent extraction, ion exchange resins, or cementation with zinc powder [24]-[31].

The application of the ion exchange resins technique is very appropriate for solutions with low content of the element of interest, because it is a process that allows concentrating solutions very selectively. The ion ex-change is a reversible chemical reaction that takes place when an ion of a solution or a dissolved complex is exchanged for another ion (or ions) of equal value that is joined to the stationary solid particle.

When anion exchange resins are used, the adsorbed complexes will be both the aurothiosulfate anions, as well as the cuprothiosulfates, plus the trithionate, tetrathionate and other higher polythionates produced by the oxidation of the thiosulfate [32]. For that reason, it becomes necessary to know the behavior of the copper complexes separately in these kinds of resins in a thiosulfate-ammonia media, because copper will always be present in the gold leaching solutions.

The adsorption of copper on ion exchange resins in thiosulfate ammonia medium has not been studied extensively. Dreisinger and Zhang determined that with strong base anion exchange resins there is a high gold load on the resin, with a high adsorption rate due to the alkaline character of the solutions coming from the leaching [33] [34]. Most information is aimed at finding the complexes formed in the copper(I/II)-thiosulfate-ammonia system by means of speciation diagrams [35].

The speciation diagrams for the system of interest allow a better understanding of the phenomena that take place, and that is how Senanayake and Muir showed the effect of $\mathrm{pH}$ on the distribution of the involved species. For the copper(II)-thiosulfate-ammonia system they found that the predominant species at $\mathrm{pH}$ lower than $7.5 \mathrm{is} \mathrm{Cu}\left(\mathrm{S}_{2} \mathrm{O}_{3}\right)_{2}^{3-}$, with $0.1 \mathrm{M}$ concentrations of thiosulfate and ammonia; on the contrary, at higher ammonia concentrations and higher $\mathrm{pH}$, but less than 12 , the predominant species is $\mathrm{Cu}\left(\mathrm{NH}_{3}\right)_{4}^{2+}$.

The objective of this work was to study experimentally by means of discontinuous tests the effect of different variables such as $\mathrm{pH}$, thiosulfate, ammonia and copper con-

centrations in the adsorption of copper complexes in the $\mathrm{Cu}\left(\mathrm{S}_{2} \mathrm{O}_{3}\right)_{2}^{3-}$ form on the DOWEX 550A ion exchange resin. The effect of the sulfite and perchlorate ions on the desorption of gold from the resin was also studied.

\section{Experimental}

\subsection{Materials}

The ion exchange resin used was DOWEX 550A (Dow Chemical Company), classified 
as a type 1 strong base. In its internal structure it has a quaternary amine functional group, and its outer appearance is as gel-type uniform particles with an average size of $590 \pm 50 \mu \mathrm{m}$.

For the preparation of the copper solution and the eluting solutions double distilled and deionized water was used and analytical grade reagents, such as copper(II) sulfate pentahydrate $\left[\mathrm{CuSO}_{4} \cdot 5 \mathrm{H}_{2} \mathrm{O}\right]$, sodium thiosulfate $\left[\mathrm{Na}_{2} \mathrm{~S}_{2} \mathrm{O}_{3} \cdot 5 \mathrm{H}_{2} \mathrm{O}\right]$, ammonium hydroxide $\left[\mathrm{NH}_{4} \mathrm{OH}\right]$, sodium hydroxide $[\mathrm{NaOH}]$, sodium perchlorate $\left[\mathrm{NaClO}_{4} \cdot 2 \mathrm{H}_{2} \mathrm{O}\right]$, and sodium sulfite $\left[\mathrm{Na}_{2} \mathrm{SO}_{3}\right]$. All reagents were purchased from Sigma-Aldrich.

\subsection{Experimental Techniques}

The adsorption tests were carried out in 500-mL reactors with mechanical stirring, keeping constant the following experimental parameters: contact time: $3 \mathrm{~h}$, temperature: $298 \mathrm{~K}$, aqueous solution volume: $400 \mathrm{~mL}$, solution/resin ratio: $833.3 \mathrm{~mL} / \mathrm{g}$.

In this stage the percentage of copper adsorbed and the resin's copper load $(\mathrm{g} \mathrm{Cu} / \mathrm{kg}$ resin) as a function of time were measured for the different experimental conditions. The studied variables and their experimentation ranges are presented in Table 1.

The experimental method used in each experiment was the same, varying only the specific conditions for each case. The following stages were used:

- The aqueous solution was added to the reactor, and the temperature and the $\mathrm{pH}$ were adjusted.

- The resin was added to the solution and the system was stirred mechanically in order to work with a perfect mixture.

- Samples of $3 \mathrm{~mL}$ were removed occasionally from the aqueous phase for the chemical analysis.

- The $\mathrm{pH}$ and the temperature of the aqueous solution were measured continuously.

- After $3 \mathrm{~h}$ the stirring was stopped, the resin was filtered from the aqueous solution, and it was washed for its later chemical analysis by atomic absorption, and the copper load on the resin was determined from the copper balance present in the solutions.

For the elution tests, the resin was loaded and the desorption experiments were performed in 500-mL reactors with mechanical stirring, keeping the following experimental conditions elutant: $\mathrm{Cu}$ load on the resin: $17.4 \mathrm{~g} \mathrm{Cu} / \mathrm{kg}$ resin, $\mathrm{pH}: 11$, temperature: $298 \mathrm{~K}$, contact time: $3 \mathrm{~h}$, solution/resin ratio: $200 \mathrm{~mL} / \mathrm{g}$, volume of aqueous solution: $300 \mathrm{~mL}$.

Table 1. Variables and experimental ranges in the adsorption stage.

\begin{tabular}{cc}
\hline Variable & Experimental range \\
\hline $\mathrm{pH}$ & $9-11$ \\
Thiosulfate concentration & $0.1-0.5 \mathrm{M}$ \\
Ammonia concentration & $0.1-0.5 \mathrm{M}$ \\
Copper concentration & $50-200 \mathrm{ppm}$ \\
\hline
\end{tabular}


In this stage the copper concentration in the rich solution was determined, and the percentage of desorbed copper as a function of time for the different experimental conditions was determined. The studied variables and their experimental ranges are shown in Table 2.

In this case the experimental method was the following:

- The copper bearing resin was loaded in agreement with the experimental conditions studied in the previous stage.

- The aqueous eluting solution was added and the temperature and the $\mathrm{pH}$ were adjusted to the required values.

- The loaded resin was added and the system was stirred mechanically.

- Samples of $3 \mathrm{~mL}$ were removed occasionally from the aqueous phase for the chemical analysis.

- The $\mathrm{pH}$ and the temperature of the aqueous solution were measured continuously.

- After $3 \mathrm{~h}$ the stirring was stopped, the resin was filtered from the aqueous solution, and it was washed.

- The same as in the previous stage, the analyses were performed by atomic absorption.

\section{Results and Discussion}

\subsection{Adsorption Stage}

\subsubsection{Effect of $\mathrm{pH}$}

Figure 1 shows the results of the effect of $\mathrm{pH}$ on the copper adsorption on the Dowex $550 \mathrm{~A}$ resin. In general, the adsorption did not exceed $10 \%$ at best, and the general shape of these curves indicates that initially the copper is adsorbed at a fast rate in all cases until a maximum value is reached, and then there is a small drop in the adsorption that can be attributed to a partial desorption of the copper.

The amount of adsorbed copper indicates that the process improves at $\mathrm{pH} 11$ in relation to $\mathrm{pH}$ 9. The greater adsorption at $\mathrm{pH} 11$ can be attributed to the greater stability of the thiosulfate at that $\mathrm{pH}$, generating less tetrathionate $\left(\mathrm{S}_{2} \mathrm{O}_{6}^{2-}\right)$ which acts as a competitor of the $\mathrm{Cu}\left(\mathrm{S}_{2} \mathrm{O}_{3}\right)_{2}^{3-}$ complex in the adsorption process. The reason for the drops of these curves (due to partial desorption) can be attributed to a critical concentration of tetrathionate that causes this situation, and this agrees with the fact that at $\mathrm{pH}$ 9 partial desorption takes place in shorter solution-resin contact times. The chemical equilibrium that accounts for this situation can be represented by the following equation.

$$
2 \mathrm{Cu}\left(\mathrm{NH}_{3}\right)_{4}^{2+}+6 \mathrm{~S}_{2} \mathrm{O}_{3}^{2-} \rightarrow 2 \mathrm{Cu}\left(\mathrm{S}_{2} \mathrm{O}_{3}\right)_{2}^{3-}+\mathrm{S}_{2} \mathrm{O}_{6}^{2-}+8 \mathrm{NH}_{3}
$$

Table 2. Variables and experimental ranges in the elution stage.

\begin{tabular}{cc}
\hline Variable & Experimental range \\
\hline Sodium sulfite concentration & $0.1-0.5 \mathrm{M}$ \\
Sodium perchlorate concentration & $0.1-0.5 \mathrm{M}$ \\
\hline
\end{tabular}




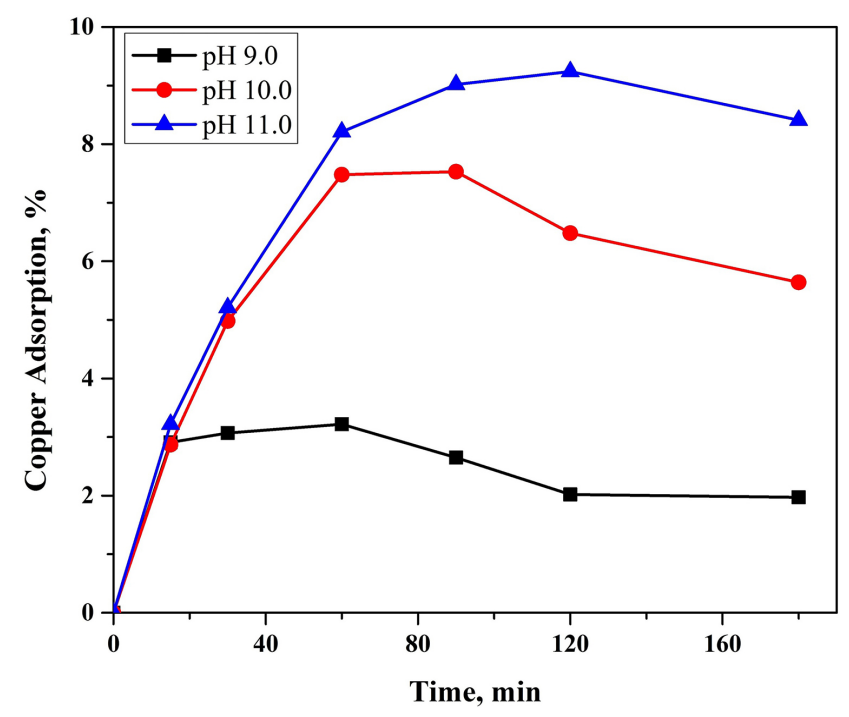

Figure 1. Effect of $\mathrm{pH}$ on copper adsorption. Conditions: 200 ppm Cu; $0.1 \mathrm{M}$ ammonia; $0.1 \mathrm{M}$ thiosulfate.

\subsubsection{Effect of Thiosulfate Concentration}

Figure 2 shows the results of the effect of thiosulfate on the copper adsorption and load, and it is seen that as the concentration of thiosulfate increases the percentage of adsorbed copper decreases.

When the concentration of thiosulfate is between 0.3 and $0.5 \mathrm{M}, 2 \%$ to $3 \%$ of $\mathrm{Cu}$ is adsorbed, achieving a copper load on the resin of 3 to $4 \mathrm{~g} \mathrm{Cu} / \mathrm{kg}$ resin. But working with a $0.1 \mathrm{M}$ thiosulfate concentration the adsorption rises to $8 \%$, with a load of approximately $17 \mathrm{~g} \mathrm{Cu} / \mathrm{kg}$ resin. This situation is explained because the thiosulfate would act as a competitor of copper for the resin's active sites. According to reaction (3), a lower concentration of thiosulfate generates less tetrathionate, which, as already mentioned, competes with the copper complex in the adsorption process.

Figure 3 shows the adsorption of copper at different thiosulfate concentrations and different contact times. It is seen that for $0.5 \mathrm{M}$ thiosulfate there is no variation in the percentage of adsorbed copper for the different solution-resin contact times, but for a 0.1 M initial thiosulfate concentration the amount of adsorbed copper is a function of time. This behavior can be attributed to the coadsorption of the anionic thiosulfate complexes on the resin. The stoichiometry that represents the adsorption of thiosulfate can be described by the following equation:

$$
2 \mathrm{R}^{+} \mathrm{OH}^{-}+\mathrm{S}_{2} \mathrm{O}_{3}^{2-} \rightarrow \mathrm{R}_{2}^{+}\left(\mathrm{S}_{2} \mathrm{O}_{3}\right)^{2-}+2^{+} \mathrm{OH}^{-}
$$

\subsubsection{Effect of Ammonia Concentration}

Figure 4 presents the results of copper load on the Dowex 550A resin as the ammonia concentration is varied. It is seen that as the concentration of dissolved ammonia increases, the copper adsorption and load on the resin decrease. This may be due to the fact that as the ammonia concentration increases, the stability of the $\mathrm{Cu}\left(\mathrm{NH}_{3}\right)_{4}^{2+}$ complex in relation to the formation of the $\mathrm{Cu}\left(\mathrm{S}_{2} \mathrm{O}_{3}\right)_{2}^{3-}$ complex increases. 
Speciation diagrams were made of the $\mathrm{Cu}-\mathrm{NH}_{3}-\mathrm{S}_{2} \mathrm{O}_{3}^{2-}$ system under the experimental temperature and electrochemical potential conditions. Figure 5 shows that as the amount of ammonia in the solution increases, the stability of the copper-thiosulfate complexes decreases, the presence of the copper-ammonia complex becoming more important, so that at an $\mathrm{NH}_{3}$ concentration of $500 \mathrm{mM}$ the copper-thiosulfate complexes disappear.

At higher ammonia concentrations the following situations occur:

- The formation of cuprotetramine, $\mathrm{Cu}\left(\mathrm{NH}_{3}\right)_{4}^{2+}$, becomes more important

- There will be a greater amount of free thiosulfate, which may cause a greater production of tetrathionate, causing a decrease of the adsorption of the $\mathrm{Cu}\left(\mathrm{S}_{2} \mathrm{O}_{3}\right)_{2}^{3-}$ complex, as shown in Figure 5.



Figure 2. Effect of thiosulfate on copper adsorption. Conditions: 200 ppm Cu; $0.1 \mathrm{M}$ ammonia; $\mathrm{pH} 11$.

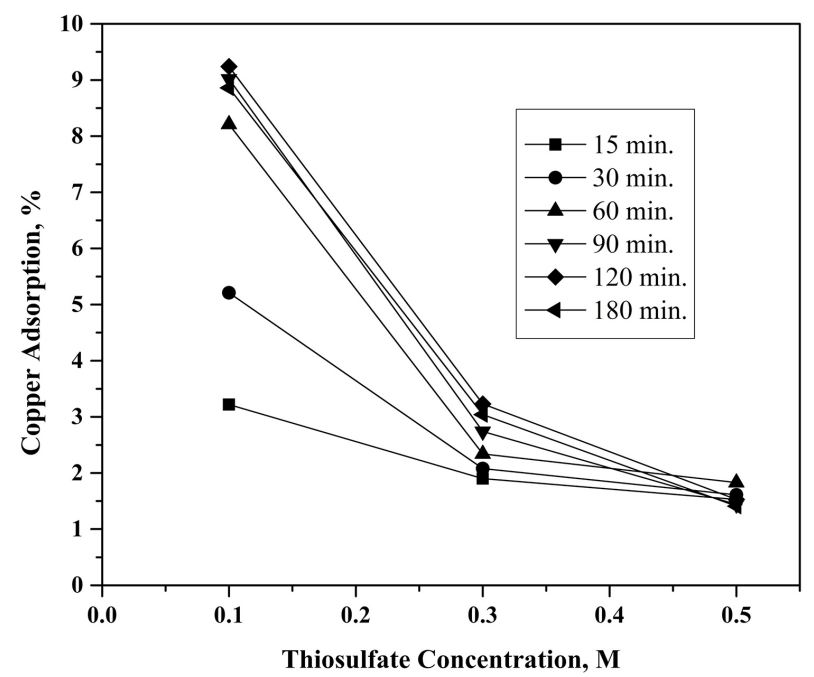

Figure 3. Variation of copper adsorption with thiosulfate concentration. Conditions: 200 ppm Cu; $0.1 \mathrm{M}$ ammonia; pH 11. 


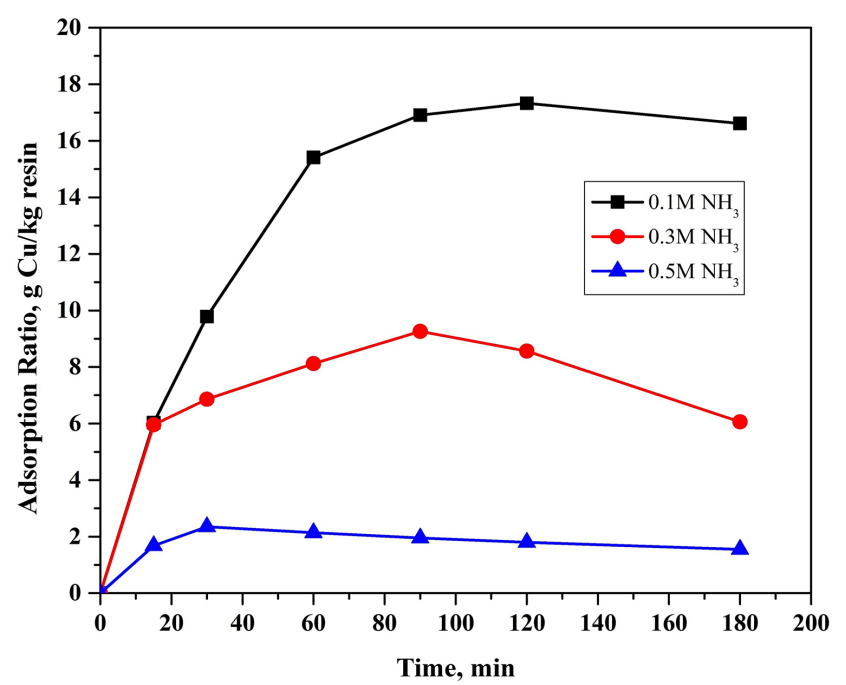

Figure 4. Effect of ammonia on copper load. Conditions: $200 \mathrm{ppm} \mathrm{Cu} 0.1 \mathrm{M}$ thiosulfate; $\mathrm{pH} 11$.
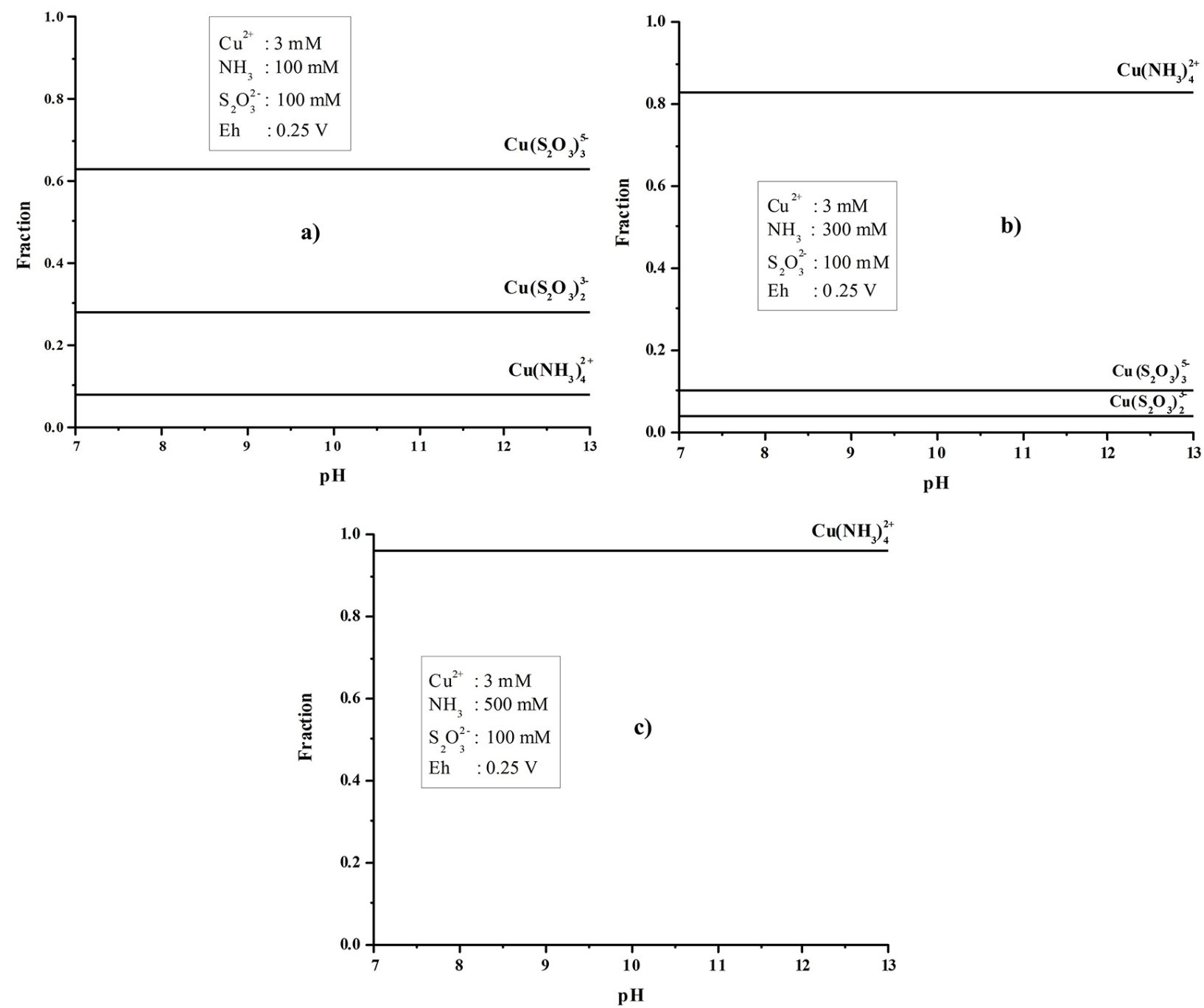

Figure 5. Speciation of the $\mathrm{Cu}-\mathrm{NH}_{3}-\mathrm{SO}_{3}^{2-}$ system at $25^{\circ} \mathrm{C}$. 


\subsubsection{Effect of Copper Concentration}

Figure 6 shows the effect of the concentration of dissolved copper on the copper load on the resin. Under the experimental conditions such as $\mathrm{pH}$, and $\mathrm{NH}_{3}$ and $\mathrm{S}_{2} \mathrm{O}_{3}^{2-}$ concentration, the adsorption of copper on the resin takes place according to the following stoichiometry:

$$
3 \mathrm{ROH}^{-}+\mathrm{Cu}\left(\mathrm{S}_{2} \mathrm{O}_{3}\right)_{2}^{3-} \rightarrow \mathrm{Cu}\left(\mathrm{S}_{2} \mathrm{O}_{3}\right) \mathrm{R}_{3}+3 \mathrm{OH}^{-}
$$

As the dissolved copper concentration increases, the copper load on the resin also increases. For the three copper concentrations studied there was a slight desorption after 90 to 120 minutes of solution-resin contact.

\subsection{Desorption Stage}

The elution or desorption tests were performed to replace the $\mathrm{Cu}\left(\mathrm{S}_{2} \mathrm{O}_{3}\right)_{2}^{3-}$ complex loaded on the resin by the sulfite or perchlorate eluent anion. Initially the resin was loaded with $17.4 \mathrm{~g} \mathrm{Cu} / \mathrm{kg}$ resin. This load was obtained by contacting the resin with an aqueous solution of $200 \mathrm{ppm} \mathrm{Cu} ; 0.1 \mathrm{M}$; and $0.1 \mathrm{M} \mathrm{NH}_{3}$ at $\mathrm{pH} 11$ during $2 \mathrm{~h}$ of resinsolution contact, at a constant temperature of $25^{\circ} \mathrm{C}$.

\subsubsection{Elution of Copper with Perchlorate $\left(\mathrm{ClO}_{4}^{-}\right)$Solutions}

Figure 7 shows the kinetics of copper elution from the loaded resin by an aqueous solution with different perchlorate concentrations. Increasing the concentration of perchlorate from $0.1 \mathrm{M}$ to $0.5 \mathrm{M}$ did not cause an important increase in the desorption of the copper complex from the resin after 155 minutes of solution-resin contact. The following stoichiometry represents the desorption reaction of the $\mathrm{Cu}\left(\mathrm{S}_{2} \mathrm{O}_{3}\right)_{2}^{3-}$ copper complex from the ion exchange resin by perchlorate:

$$
\mathrm{R}_{3}^{+}\left[\mathrm{Cu}\left(\mathrm{S}_{2} \mathrm{O}_{3}\right)_{2}\right]^{3-}+3 \mathrm{ClO}_{4}^{-} \rightarrow 3 \mathrm{R}^{+}\left(\mathrm{ClO}_{4}\right)_{3}^{-}+\left[\mathrm{Cu}\left(\mathrm{S}_{2} \mathrm{O}_{3}\right)_{2}\right]^{3-}
$$

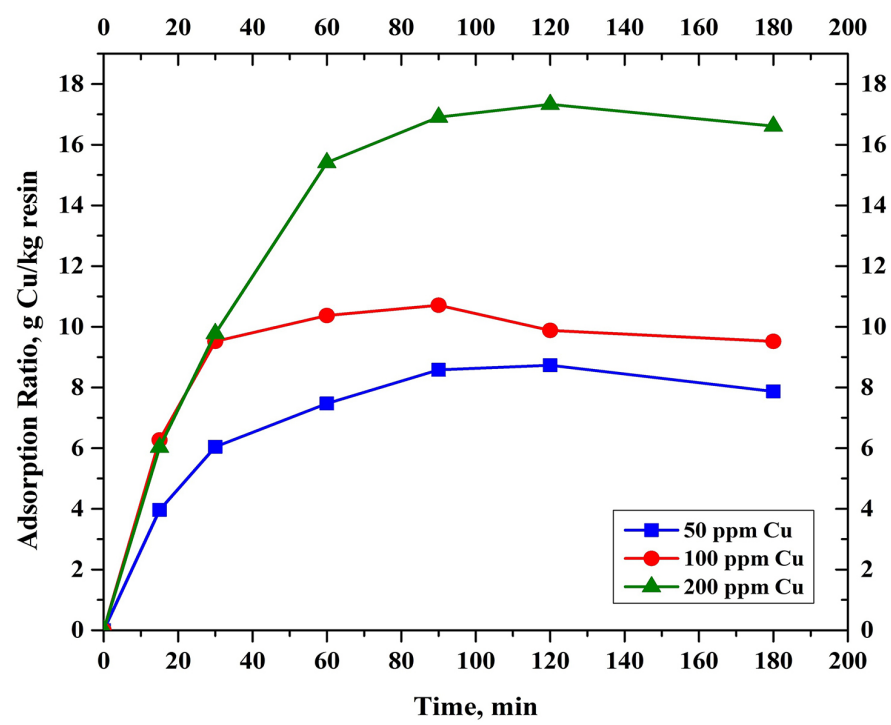

Figure 6. Effect of initial copper concentration and its adsorption in the resin. Conditions: $\mathrm{pH} 11 ; 0.1 \mathrm{M}$ ammonia; $0.1 \mathrm{M}$ thiosulfate. 


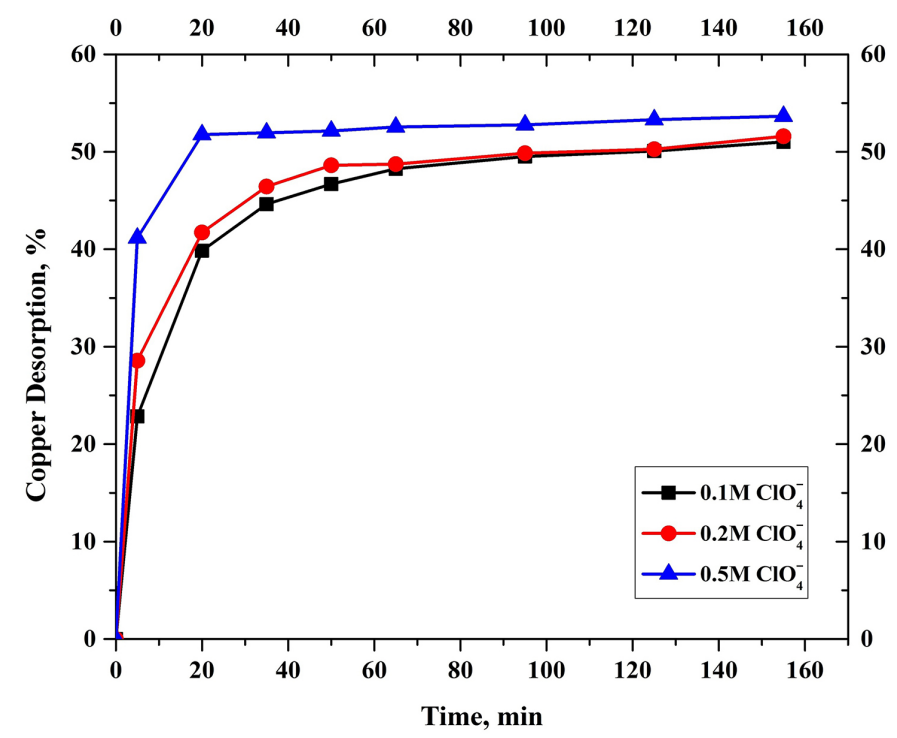

Figure 7. Effect of perchlorate in the copper elution. Conditions: resin loaded with $17.35 \mathrm{~g} \mathrm{Cu} / \mathrm{kg}$ resin; 0.1 M ammonia; $\mathrm{pH} 11$.

As the perchlorate concentration was increased from $0.1 \mathrm{M}$ to $0.5 \mathrm{M}$, the initial exchange rate increased considerably (reaction 6), so that working with a $0.5 \mathrm{M}$ perchlorate concentration the maximum copper elution of $50 \%$ was achieved after 20 minutes of solution-resin contact. But using 0.1 and $0.2 \mathrm{M} \mathrm{ClO}_{4}^{-}$, after the 20 minutes of contact $39 \%$ and $41 \%$ desorption of copper was achieved.

\subsubsection{Elution of Copper with Sulfite $\left(\mathrm{SO}_{3}^{2-}\right)$ Solutions}

Figure 8 shows the effect of sulfite concentration in the eluent solution on the elution of copper from the loaded resin. The results show that the elution of the $\mathrm{Cu}\left(\mathrm{S}_{2} \mathrm{O}_{3}\right)_{2}^{3-}$ complex with sulfite is very efficient and fast. Working with $0.1 \mathrm{M}$ and $0.2 \mathrm{M} \mathrm{SO}_{3}^{2-}$ concentrations, elutions close to $80 \%$ were achieved after $150 \mathrm{~min}$ of solution-resin contact, and $99 \%$ working with $0.5 \mathrm{M} \mathrm{SO}_{3}^{2-}$ after 30 min of contact. The stoichiometry of the elution of copper with sulfite is given by:

$$
2 \mathrm{R}_{3}^{+}\left[\mathrm{Cu}\left(\mathrm{S}_{2} \mathrm{O}_{3}\right)_{2}\right]^{3-}+3 \mathrm{SO}_{3}^{2-} \rightarrow 3 \mathrm{R}_{3}^{+} \mathrm{SO}_{3}^{2-}+2\left[\mathrm{Cu}\left(\mathrm{S}_{2} \mathrm{O}_{3}\right)_{2}\right]^{3-}
$$

Sulfite solutions were more efficient than those of perchlorate for eluting the $\mathrm{Cu}\left(\mathrm{S}_{2} \mathrm{O}_{3}\right)_{2}^{3-}$ complex from the resin, which in an industrial process has the effect of working with a smaller inventory of eluent solution, in addition to yielding solutions with higher copper concentrations.

\section{Conclusions}

Under different experimental conditions the $\mathrm{Cu}\left(\mathrm{S}_{2} \mathrm{O}_{3}\right)_{2}^{3-}$ complex can be adsorbed by a strong base ion exchange resin like DOWEX 550A. In the $\mathrm{pH}$ range studied, increasing this parameter from 9 to 11 favors the adsorption of copper, reaching a load of 5.86 $\mathrm{kg} \mathrm{Cu} /$ ton resin at $\mathrm{pH} 9$ and 60 minutes of solution-resin contact, and $16.91 \mathrm{~kg} \mathrm{Cu} / \mathrm{ton}$ 


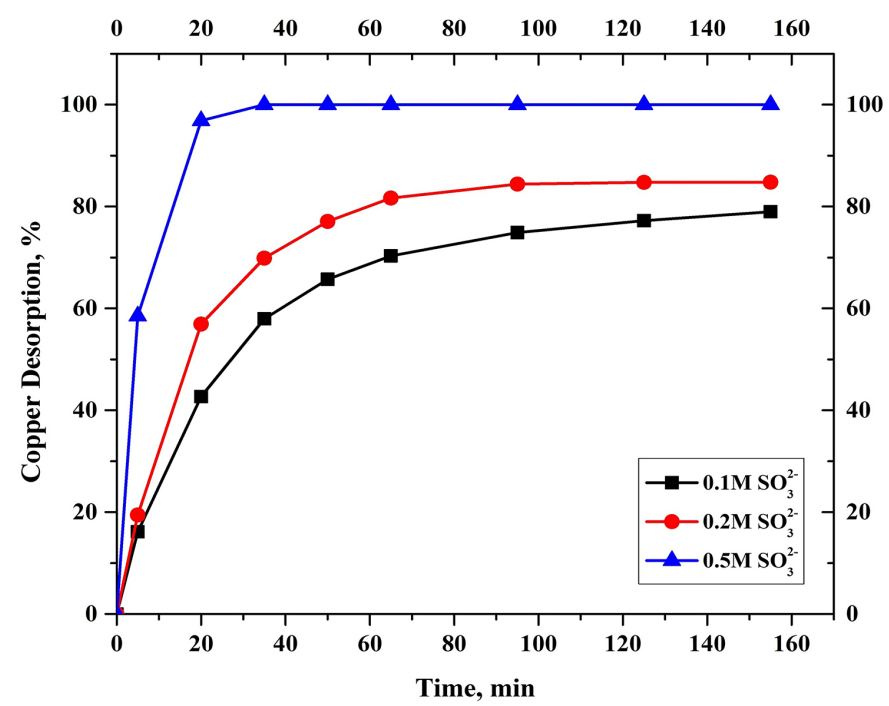

Figure 8. Effect of sulfite in the copper elution. Conditions: resin loaded with $17.35 \mathrm{~g} \mathrm{Cu} / \mathrm{kg}$ resin; $0.1 \mathrm{M}$ ammonia; $\mathrm{pH} 11$.

resin at $\mathrm{pH} 11$ after 90 minutes of contact. Increasing the concentration of thiosulfate in the aqueous solution $(0.1 \mathrm{M}$ to $0.5 \mathrm{M})$ decreases the adsorption of the $\mathrm{Cu}\left(\mathrm{S}_{2} \mathrm{O}_{3}\right)_{2}^{3-}$ complex. Increasing the ammonia content in the solution increases the stability of the cuprotetramine, decreasing the amount of copper-thiosulfate complex, producing a lower adsorption of copper on the resin.

Elution of the copper complexes from the resin with sulfite ions is better and faster than with perchlorate ions. A good elution with sulfite is beneficial because this anion is part of the thiosulfate oxidation system. Elution with sulfite ion is more sensitive to changes in concentration, achieving $100 \%$ elution for a $0.5 \mathrm{M}$ and $84.79 \%$ elution for $0.2 \mathrm{M}$, while elution was $53.65 \%$ at $0.5 \mathrm{M}$ perchlorate concentration and $51.59 \%$ at 0.2 $\mathrm{M}$ concentration.

\section{Acknowledgements}

Support by the Dirección de Investigaciones Científicas y Tecnológicas of the Universidad de Santiago de Chile (DICYT) through project 051414ND is gratefully acknowledged.

\section{References}

[1] Zipperian, D. and Raghavan, S. (1998) Gold and Silver Extraction by Ammoniacal Thiosulfate Leaching from a Rhyolite Ore. Hydrometallurgy, 19, 361-375. http://dx.doi.org/10.1016/0304-386x(88)90041-2

[2] Langhans, J.W., Lei, K.P. and Carnahan, T.G. (1992) Copper-Catalyzed Thiosulfate Leaching of Low-Grade Gold Ores. Hydrometallurgy, 29, 191-203. http://dx.doi.org/10.1016/0304-386x(92)90013-p

[3] Abbruzzese, C., Fornari, P., Massidda, R., Veglio, F. and Ubaldini S. (1995) Thiosulphate Leaching for Gold Hydrometallurgy. Hydrometallurgy, 39, 265-276. http://dx.doi.org/10.1016/0304-386x(95)00035-f 
[4] Breuer, P.L. and Jeffrey, M.I. (2000) Thiosulfate Leaching Kinetics of Gold in the Presence of Copper and Ammonia. Minerals Engineering, 13, 1071-1081.

http://dx.doi.org/10.1016/s0892-6875(00)00091-1

[5] Aylmore, M.G. and Muir, D.M. (2000) Thiosulfate Leaching of Gold-A Review. Minerals Engineering, 14, 135-174. http://dx.doi.org/10.1016/s0892-6875(00)00172-2

[6] Jeffrey, M.I. (2001) Kinetics Aspects of Gold and Silver Leaching in Ammonia-Thiosulfate Solutions. Hydrometallurgy, 60, 7-16. http://dx.doi.org/10.1016/s0304-386x(00)00151-1

[7] Schmitz, P.A., Duyvesteyn, S., Johnson, W.P., Enloe, L. and McMullen, J. (2001) Ammoniacal Thiosulfate and Sodium Cyanide Leaching of Preg-Robbing Goldstrike Ore Carbonaceous Matter. Hydrometallurgy, 60, 25-40. http://dx.doi.org/10.1016/s0304-386x(00)00154-7

[8] Navarro, P., Vargas, C., Villarroel, A. and Alguacil, F.J. (2002) On the Use of Ammoniacal/ Ammonium Thiosulphate for Gold Extraction from a Concentrate. Hydrometallurgy, 65, 37-42. http://dx.doi.org/10.1016/s0304-386x(02)00062-2

[9] Molleman, E. and Dreisinger, D. (2002) The Treatment of Copper-Gold Ores by Ammonium Thiosulfate Leaching. Hydrometallurgy, 66, 1-21. http://dx.doi.org/10.1016/s0304-386x(02)00080-4

[10] Breuer, P.L. and Jeffrey, M.I. (2003) The Reduction of Copper(II) and the Oxidation of Thiosulfate and Oxysulfur Anions in Gold Leaching Solutions. Hydrometallurgy, 70, 163173. http://dx.doi.org/10.1016/s0304-386x(03)00078-1

[11] Chu, C.K., Breuer, P.L. and Jeffrey, M.I. (2003) The Impact of Thiosulfate Oxidation Products on the Oxidation of Gold in Ammonia Thiosulfate Solutions. Minerals Engineering, 16, 265-271. http://dx.doi.org/10.1016/s0892-6875(02)00369-2

[12] Wan, R. and LeVier, K. (2003) Solution Chemistry Factors for Gold Thiosulfate Heap Leaching. International Journal of Mineral Processing, 72, 311-322. http://dx.doi.org/10.1016/s0301-7516(03)00107-8

[13] Jeffrey, M.I., Breuer, P.L. and Chu, C.K. (2003) The Importance of Controlling Oxygen Addition during the Thiosulfate Leaching of Gold Ores. International Journal of Mineral Processing, 72, 323-330. http://dx.doi.org/10.1016/s0301-7516(03)00108-x

[14] Muir, D.M. and Aylmore, M.G. (2004) Thiosulphate as an Alternative to Cyanide for Gold Processing-Issues and Impediments. Mineral Processing and Extractive Metallurgy, 113, 2-12. http://dx.doi.org/10.1179/037195504225004661

[15] Zhang, X.M., Senanayake, G. and Nicol, M.J. (2004) A Study of the Gold Colloid Dissolution Kinetics in Oxygenated Ammoniacal Thiosulfate Solutions. Hydrometallurgy, 74, 243-257. http://dx.doi.org/10.1016/j.hydromet.2004.05.007

[16] Senanayake, G. (2004) Gold Leaching in Non-Cyanide Lixiviant Systems: Critical Issues on Fundamentals and Applications. Minerals Engineering, 17, 785-801.

http://dx.doi.org/10.1016/j.mineng.2004.01.008

[17] Senanayake, G. (2005) Role of Copper(II), Carbonate and Sulphite in Gold Leaching and Thiosulphate Degradation by Oxygenated Alkaline Non-Ammoniacal Solutions. Minerals Engineering, 18, 409-426. http://dx.doi.org/10.1016/j.mineng.2004.08.001

[18] Senanayake, G. (2005) A Surface Adsorption/Reaction Mechanism for Gold Oxidation by Copper(II) in Ammoniacal Thiosulfate Solutions. Journal of Colloid and Interface Science, 286, 253-257. http://dx.doi.org/10.1016/j.jcis.2004.12.041

[19] Feng, D. and van Deventer, J.S. (2006) Ammoniacal Thiosulphate Leaching of Gold in the Presence of Pyrite. Hydrometallurgy, 82, 126-132. http://dx.doi.org/10.1016/j.hydromet.2006.03.006 
[20] Feng, D. and van Deventer, J.S. (2007) Effect of Hematite on Thiosulphate Leaching of Gold. International Journal of Mineral Processing, 82, 138-147.

http://dx.doi.org/10.1016/j.minpro.2006.09.003

[21] Feng, D. and van Deventer, J.S. (2007) The Role of Oxygen in Thiosulphate Leaching of Gold. Hydrometallurgy, 85, 193-202. http://dx.doi.org/10.1016/j.hydromet.2006.09.003

[22] Heath, J.A., Jeffrey, M.I., Zhang, H.G. and Rumball, J.A. (2008) Anaerobic Thiosulfate Leaching: Development of in Situ Gold Leaching Systems. Minerals Engineering, 21, 424433. http://dx.doi.org/10.1016/j.mineng.2007.12.006

[23] Jeffrey, M.I., Watling, K., Hope, G.A. and Woods, R. (2008) Identification of Surface Species That Inhibit and Passivate Thiosulfate Leaching of Gold. Minerals Engineering, 21, 443-452. http://dx.doi.org/10.1016/j.mineng.2008.01.006

[24] Zhao, J., Wu, Z. and Chen, J. (1997) Extraction of Gold from Thiosulfate Solutions with Alkyl Phosphorus Esters. Hydrometallurgy, 46, 363-372. http://dx.doi.org/10.1016/S0304-386X(97)00031-5

[25] Vargas, C., Cifuentes, G., Navarro, P. and Orrego, P. (2004) Anodic Behavior of Zinc in Thiosulphate Media. Revista de Metalurgia, 40, 101-108. http://dx.doi.org/10.3989/revmetalm.2004.v40.i2.249

[26] Navarro, P., Alvarez, R., Vargas, C. and Alguacil, F.J. (2004) On the Use of Zinc for Gold Cementation from Ammoniacal-Thiosulphate Solutions. Minerals Engineering, 17, 825831. http://dx.doi.org/10.1016/j.mineng.2004.02.001

[27] Kejun, L., Yen, W.T., Shibayama, A., Miyazaki, T. and Fujita, T. (2004) Gold Extraction from Thiosulfate Solution Using Trioctylmethylammonium Chloride. Hydrometallurgy, 73, 41-53. http://dx.doi.org/10.1016/j.hydromet.2003.07.007

[28] Vargas, C., Navarro, P., Araya, E., Pavez, F. and Alguacil, F.J. (2006) Recovery of Gold from Solutions with Ammonia and Thiosulfate Using Activated Carbon. Revista de Metalurgia, 42, 222-233. http://dx.doi.org/10.3989/revmetalm.2006.v42.i3.22

[29] Navarro, P., Vargas, C., Alonso, M. and Alguacil, F.J. (2006) The Adsorption of Gold on Activated Carbon from Thiosulfate-Ammoniacal Solutions. Gold Bulletin, 39, 93-97. http://dx.doi.org/10.1007/BF03215535

[30] Navarro, P., Vargas, C., Alonso, M. and Alguacil, F.J. (2007) Towards a More Environmentally Friendly Process for Gold: Models on Gold Adsorption onto Activated Carbon from Ammoniacal Thiosulfate Solutions. Desalination, 211, 58-63. http://dx.doi.org/10.1016/j.desal.2006.03.590

[31] Nicol, M.J. and O’Malley, G. (2002) Recovering Gold from Thiosulfate Leach Pulps via Ion Exchange. JOM, 54, 44-46. http://dx.doi.org/10.1007/BF02709221

[32] Navarro, P., Vargas, C., Reveco, V. and Orellana, J. (2006) Recovery of Gold from Ammonia-Thiosulfate Media with Amberlite IRA-410 Ionic Exchange Resin. Revista de Metalurgia, 42, 354-366. http://dx.doi.org/10.3989/revmetalm.2006.v42.i5.33

[33] Zhang, H. and Dreisinger, D. (2004) The Recovery of Gold from Ammoniacal Thiosulfate Solutions Containing Copper Using Ion Exchange Resin Columns. Hydrometallurgy, 72, 225-234. http://dx.doi.org/10.1016/S0304-386X(03)00183-X

[34] Zhang, H. and Dreisinger, D. (2002) The Adsorption of Gold and Copper onto Ion-Exchange Resins from Ammoniacal Thiosulfate Solutions. Hydrometallurgy, 66, 67-76. http://dx.doi.org/10.1016/S0304-386X(02)00077-4

[35] Senanayake, G. (2004) Analysis of Reaction Kinetics, Speciation and Mechanism of Gold Leaching and Thiosulfate Oxidation by Ammoniacal Copper(II) Solutions. Hydrometallurgy, 75, 55-75. http://dx.doi.org/10.1016/j.hydromet.2004.06.004 
Submit or recommend next manuscript to SCIRP and we will provide best service for you:

Accepting pre-submission inquiries through Email, Facebook, LinkedIn, Twitter, etc. A wide selection of journals (inclusive of 9 subjects, more than 200 journals)

Providing 24-hour high-quality service

User-friendly online submission system

Fair and swift peer-review system

Efficient typesetting and proofreading procedure

Display of the result of downloads and visits, as well as the number of cited articles

Maximum dissemination of your research work

Submit your manuscript at: http://papersubmission.scirp.org/

Or contact ijnm@scirp.org 